\title{
Investigating the psychometric adequacy of nostalgia inventory (NI)
}

\section{Farhad Khormaee $^{1}$, Jalil Etemaad ${ }^{2}$}

1- Associative professor of educational psychology at Shiraz university, Shiraz, Iran. ORCID: 0000-0001-58573029

2- Ph.D. candidate of educational psychology at Shiraz University, Shiraz, Iran. ORCID: 0000-0001-9395-0029

E-mail: jetemaad@gmail.com

\begin{abstract}
Introduction: Nostalgia as one of the complex emotion that discussed conceptual challenges on entity and functions of in nineteen and twenty century. Beside assessment of nostalgia is important.
\end{abstract}

Aim: our objective of this research, preparation of necessary preliminary work to using Batcho's nostalgia inventory (1995) for psychological research in Iran.

Method: in this cross sectional study, 201 graduate and Ph.D. student were participated. Then, they are respond to nostalgia inventory (NI), check manipulation test (wildschut et al, 2006) and aspiration index (kasser \& rayan, 2006).

Results: The results showed these factors: "attachment to foretime", "longing to home", "tranquility of foretime" and convergent validity and reliability evidences for NI.

Conclusion: the result was showed evidences for construct validity, convergent validity and internal consistency of NI, also result was showed gender difference in some of factors.

Keywords: nostalgia, attachment to foretime, longing to home, tranquility of foretime

How to cite this article : Khormaee F, Etemaad J. Investigating the psychometric adequacy of nostalgia inventory (NI). Shenakht Journal of Psychology and Psychiatry. 2018; 5 (3): 95-106 .URL :http://shenakht.muk.ac.ir/article-1-457-fa.pdf

Copyright $\odot 2018$ the Author (s). Published by Kurdistan University of Medical Sciences. This is an open access article distributed under the terms of the Creative Commons Attribution-Non Commercial License 4.0 (CCBY-NC), where it is permissible to download, share, remix, transform, and buildup the work provided it is properly cited. The work cannot be used commercially without permission from the journal. 


\section{بروسى كفايت روانسنجى ير سشنامهى نوستالثى (NI)}

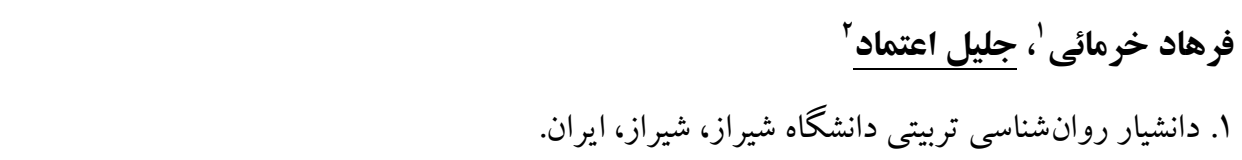

r. انشجوى د كترى روانشناسى تربيتى دانشخاه شيراز، شيراز، ايران. ايميل: jetemaad@gmail.com

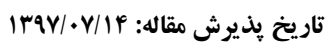

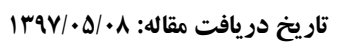

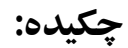

مقدمه: نوستالزى يكى از يبيجيدهترين هيجانات است كه بر سر ماهيت و كاركردهاى آن مناقشات مفهومى و نظرى تعيين

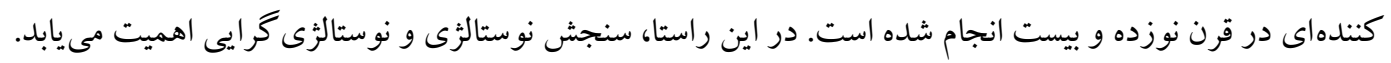
هدف: هدف از اين يزوهش، فراهم كردن مقدمات لازم جهت استفاده از يرسشنامهى نوستالزى باجو (199ه) در يزوهشهاى

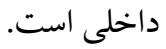

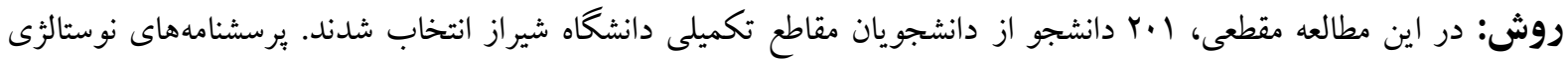

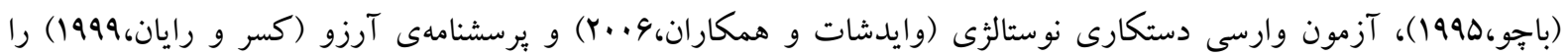

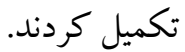

يافته ها: عامل هاى "دلبستكى هاى گذشته"، "ميل به خانه" و " صفاى گذشته" خود را نشان داد و روايى همخرا و پايايى مورد تاييد قرار گرفت. نتيجه كيرى: يافته هاى اين بذوهش مؤيد روايى سازه، همخرا و همسانى درونى و همجنين تفاوت جنسيتى در عوامل نوستالزى

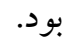
كليد وازه ها: نوستالزى، دلبستخى هاى گذشته، ميل به خانه، صفاى كذشته 
نوستالثى يكك هيجان منفى است كه مانع رشد فرد

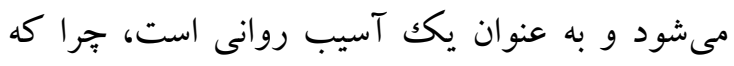
افراد به طور ناساز گارانه به كذشته مى يردازند و با غرق شدن در كذشته از مسئوليتها و از واقعيت اكنون فرار

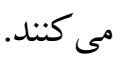
در ادامه دستهاى از يُزوهشخران با انجام تحقيقات آزمايشى و غير آزمايشى متعدد، نظريات و تحقيقات

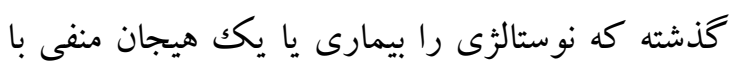

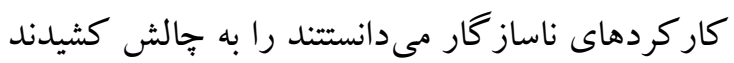
و شواهد زيادى را مبنى بر كاركردهاى مثبت اين

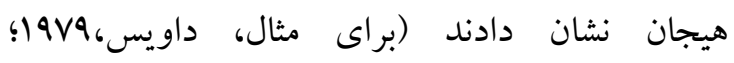

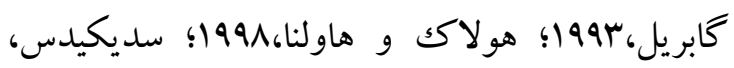

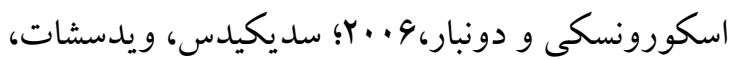

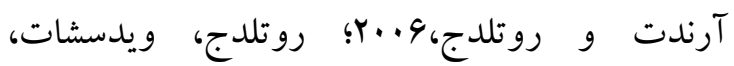

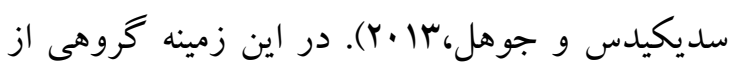
محققان نشان دادند كه محتمل است نوستالزى ايجاد كننده نشانگًان مشاهده شده باشد، امّا به طور برابر اين

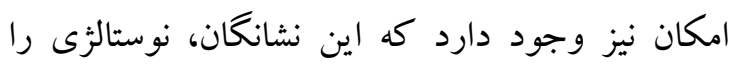

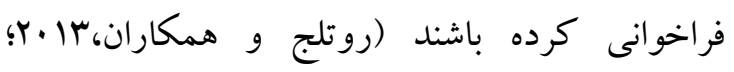

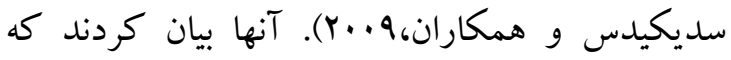
يزشكان و روانيزشكان با عدم دقّت كافى، مبتنى بر

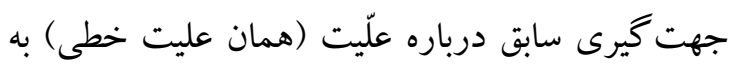
اين نتيجه رسيدهاند و نوستالزى را ايجاد كننده نشانگًان

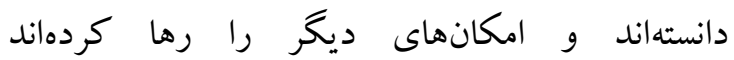

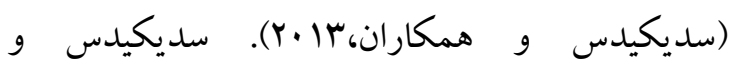

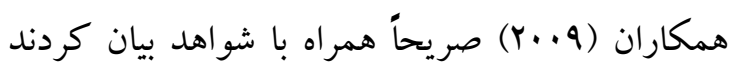

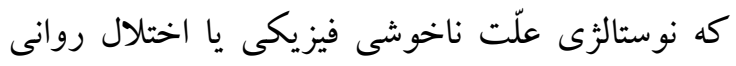

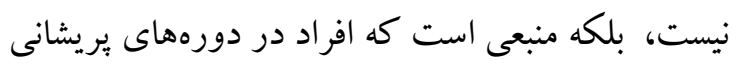
براى كمكك به خودشان و مقابله با بريشانىها از آن

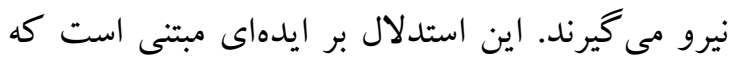

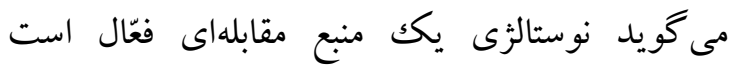

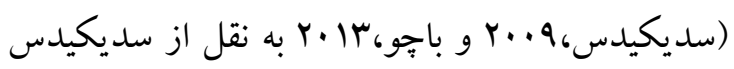

\section{مقلdمه} نوستالزى يكى از هيجاناتى است كه افراد در زندگى شخصى، آن را تجربه مى كنند و در سطوح متفاوت

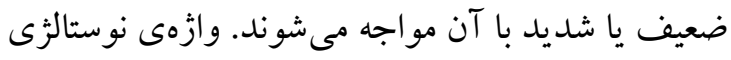

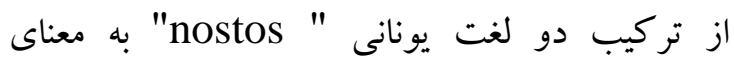

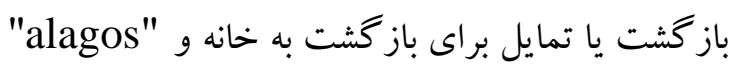
به معناى درد و رنج ساخته شده است. مفهومسازى اين هيجان، در طول دهه هاى اخير تغييرات مهم و قابل تامّلى داشته است. درزمينهى تاريخجِهى مربوط به اين هيجان شاهد تحولات مفهومى و تشخيصى هستيم. به

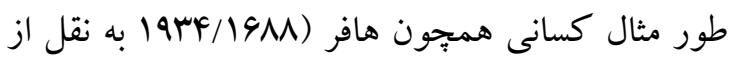

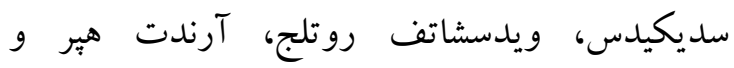

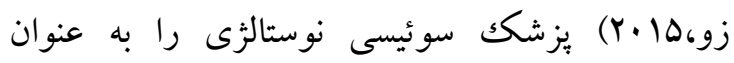
يكك"بيمارى مغزى " كه داراى نشانهاى اندوهگينى، تقلا براى گريه، ضعف، سوء هاضمه، درد معده، كم اشتهايى، انديشه يردازى درباره خودكشى و حتى

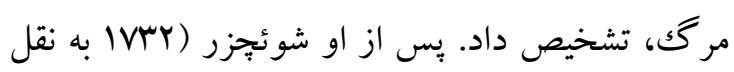

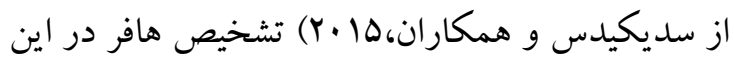

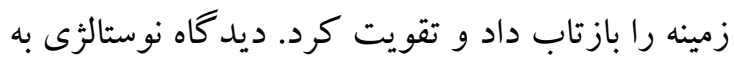
مثابه يكك بيمارى يزشكى يا نورولوزيكك تا قرن

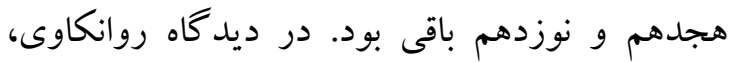

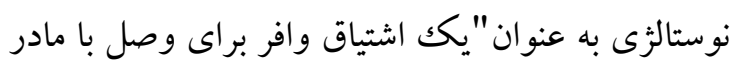
بيشاادييى، يكك وداع غمكنانه با كودكى، نوعى مكانيزم

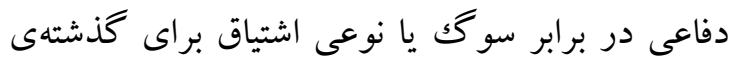

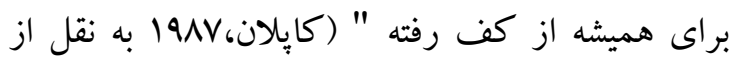

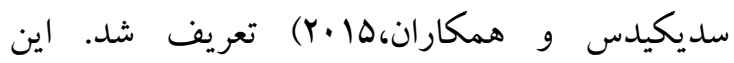
ارزيابىها با نزديكك شدن به يايان قرن بيستم كمتر شد.

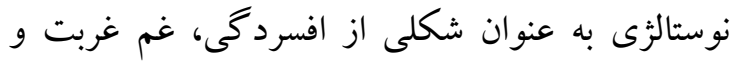

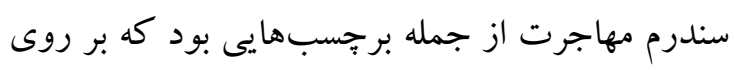

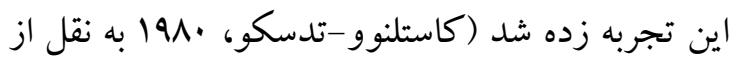

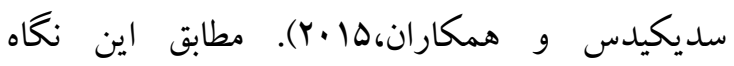


توسط يكك شبكهى عاطفى فراخوانى شده ناشى از يك محركك بيرونى به طور فعال يا منفعل، تجربه زمان حال را به تجربهى خاطرات كذشته بيوند مىزند. با اين مقدمه نظر به اهميت هيجان نوستالزّى و وابهر كار كردهاى متعددى كه بنابر شواهد تجربى دارا است، سنجش و اندازه گيرى آن نيز داراى اهميت و ضرورت بنابر است. بر اين اساس ابزارى كه بتواند تجربهى نوستالثى را بسنجد يكى از دغدغههاى بزوهشخران در اين زمينه

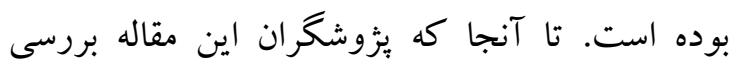
كردند حداقل دو ابزار مهم براى سنجش نوستالزى و يكك راه كار براى سنجش مداخلهى نوستالزيكك ساخته

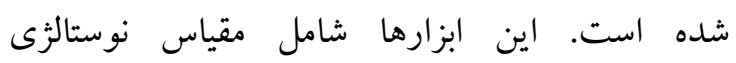

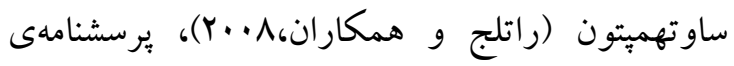
نوستالثى باجو (1990) و آزمون وارسى دستكارى

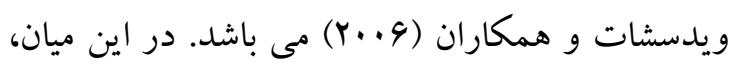

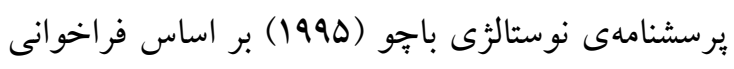

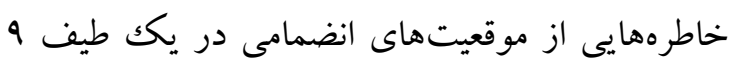
درجه اى از شدت، عمق و فراوانى، تجربه ایى نوستالزيكك را مى سنجد و بر احساس فقدان نسبت به ونه جيزهايى كه در كذشته بود و اكنون اشتياق بازيابى آن

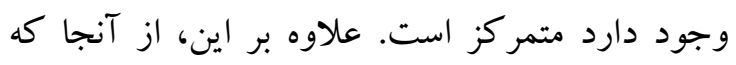

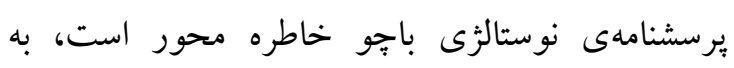

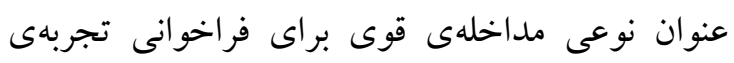
نوستالثى عمل مى كند؛ بنابراين فراهم آوردن مقدمات لازم جهت استفاده از آن در ايران ضرورى مى نمود و بُزوهش حاضر با جنين هدفى انجام بذيرفت تا موجبات

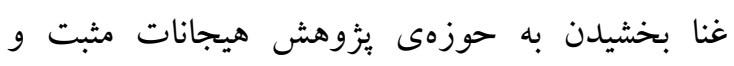
جندبعدى را در ادبيات يُزوهشى اين حوزه فراهم كند. با اين هدف، بثزوهش كنونى به دنبال بِاسخكويى به ريه سئوالات زير مى باشد: ا- وضعيت روايى سازه و

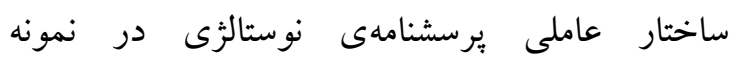

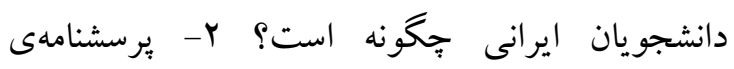

و همكاران، (Y) (Y). استدلال گفته شده به طور خاص متضمن اين است كه نوستالزى به طور مثبت همراه و

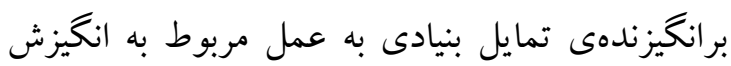

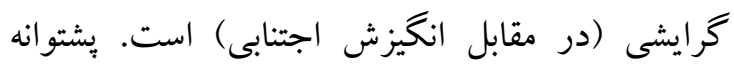
تجربى اين ادعا در تحقيقات اين محققان فراهم شده

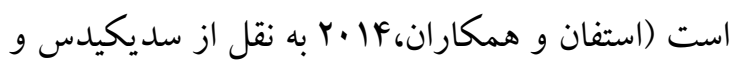

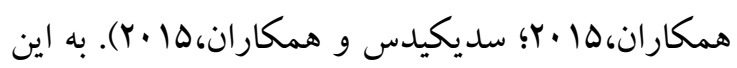

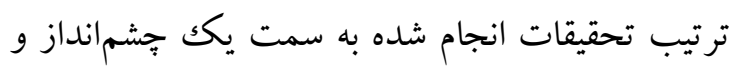
فرمول جديد براى هيجان نوستالزى رفتند. در جشمانداز جديد، نوستالزى به عنوان يكك هيجان مثبت، مربوط به خود، گذشته محور، تلخ و شيرين، آرزومندانه با كاركردهاى مثبت فردى، اجتماعى و وجودى ديده

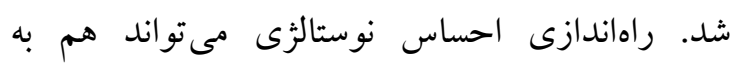

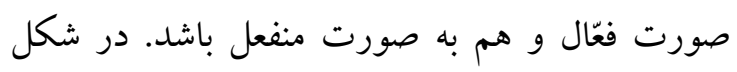

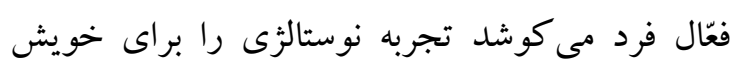

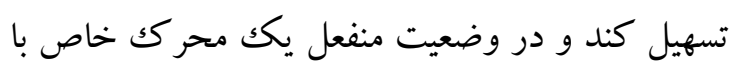

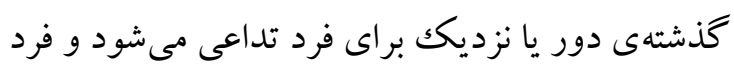
ناخواسته و غير عمدى دجار اين احساس مىشود.

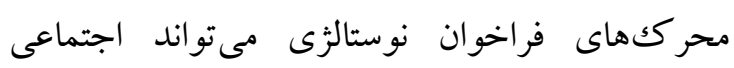
(دوستان، اعضاى خانواده، مسافرت يا تفريحها، جشن تولد، تجديد ديدار، يك عشق از دست رفته و.غيره ) و غيراجتماعى (يك شىء، حالت خلقى فرد، يك بو، تول يك موسيقى، يك محصول، دارايىها وغيره) باشد

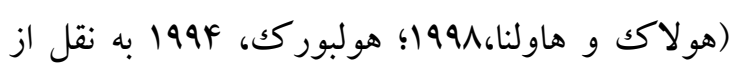
سديكيدس و همكاران، 10 1). همجينين تحقيقات نشان

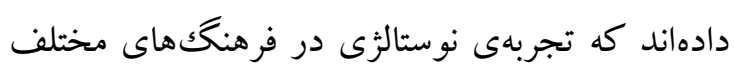

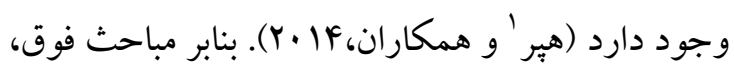

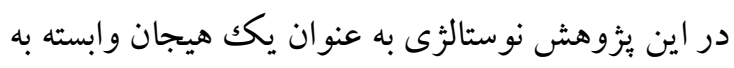

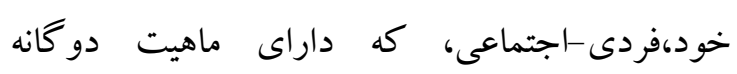

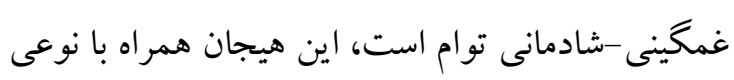
آرزومندى نسبت به كذشته و نارضايتى از اكنون كه

\section{'-Hepper}


كند. در مطالعهى باجو (19901991) شواهدى مبنى بر روايى مقدماتى اين ابزار را ارائه داده است و بايايى آن در دو مطالعه، بر اساس دو نيمهازى VA/· و بر

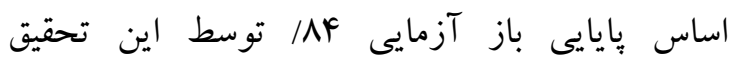
كز ارش شده است. ميزان آلفاى كرونباخ مبنى بر بايايى بائ

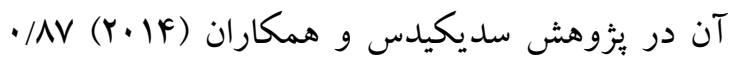

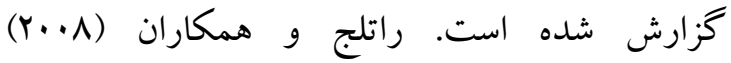

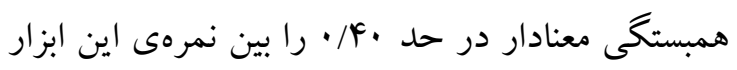
با نمرهى مقياس نوستالزى ساوتهميتون كزارش

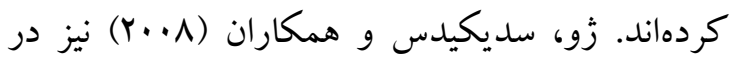
تحقيقى بر روى كارگران جينى، ضريب همبستگى

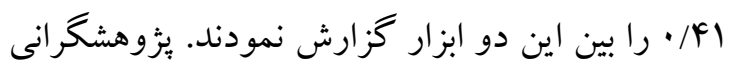

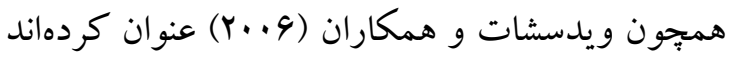
كه با توجه به جندبعدى بودن تجربهى نوستالزى و و

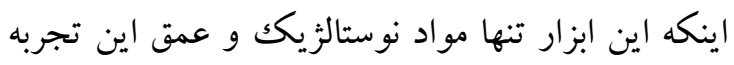
را مىتواند بسنجد و نه ويزگ گهاى ديخر، ويشنهاد كردهاند همراه با آن آزمون وارسى دست كارى ويدسشات و همكاران نيز اجرا گردد.

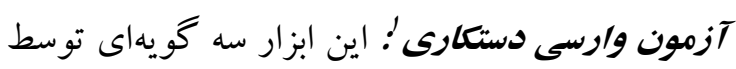
ويدسشات و همكاران (Y. (Y) ساخته شده است. از

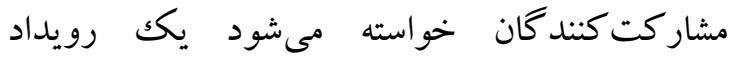
نوستالزيكك (يكى خاطرهى خوش و مهم كه از خذشته دارى و هر وقت آن به يادت مىافته دلت مى خواهد به كذشته برغردى) را به ذهن بياورند، جهار كلمه كليدى مربوط به آن رويداد را ليست كنند و مدّت كو تاهى بر رويداد و احساساتشان در ارتباط با آن تأمّل كنند. متعاقباً آنها سه آيتم وارسى دستكارى نوستالثى را تكميل كنند. گو يهها عبارت است از " در اين لحظه من كاملاً نوستالزيكك شدهام"، "اكنون من افكار عبار نوستالزيكك دارم" و "در اين لحظه من داراى احساس نوستالثى هستم". گويهها بر مقياس درجهبندى شده به لهن
نوستالثى تا جه ميزان داراى داراى روايى همخراى مطلوب مىباشد؟ ب- يرسشنامهى نوستالزى تا جه ميزان براى سنجش احساس نوستالثى دانشجويان ايرانى از

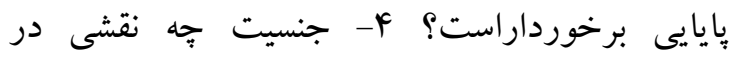

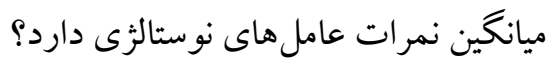

روش شركت كنند كان يُوهش حاضر ابr نفر از دانشجويان تحصيلات تكميلى رشته هاى مختلف ساكن خو ابكاههاى دانشگاه شيراز بودند كه در سال تحصيلى 94-هوrا مشغول به تحصيل بودند. از آنجا كه هدف بزوهش حاضر تعيين خصوصيات روانسنجى مقياس كرايش به نوستالثى بود مبناى تعيين حجم نمونه بر اساس تعداد گويه اين مقياس تعيين شد كه برابر ملاكك

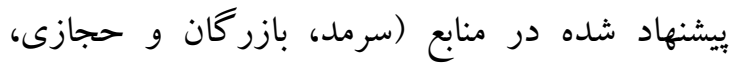
و I INAV

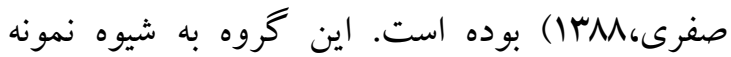
كيرى در دسترس انتخاب شدند. به اين ترتيب كه به درب اتاقها در خو ابگاهاى دختران و بسران مر اجعه و از دانشجويان كارشناسى ارشد و دكترى حاضر در اتاق درخواست شد كه مقياس ها را تكميل كنند.

ابزار يرسشنامهى نوسنالثى باجو (9901): اين مقياس توسط

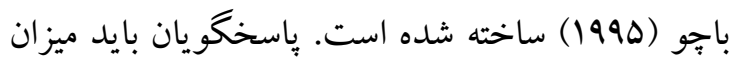
نوستالزيك بودن خاطراتشان در مورد ·r مادىى فراخوانى كننده، در يكك طيف 9 درجهاى از هر گز تا بسيار زياد را مشخص كنند. اين آيتمها شامل مواردى

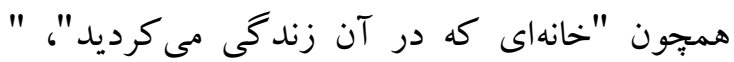
شخصى كه دوست داشتيد"، " نداشتن نخرانى" و غيره است كه از فرد خواسته مى شود ميزان احساس فقدان و

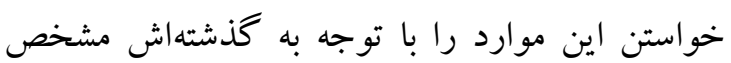




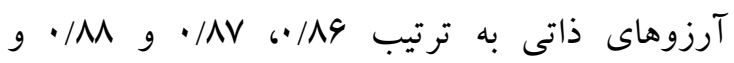
همسانى درونى اهميت، احتمال دستيابى و ميزان دستيابى به آرزوهاى بيرونى به ترتيب AV/ •، AN/ و و ( در اين يزوهش براى تعيين روايى سازهى ابزار نوستالزى از تحليل عامل اكتشافى و سبس تحليل عامل

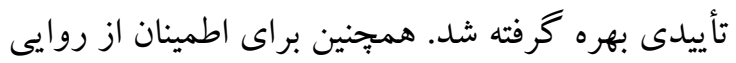

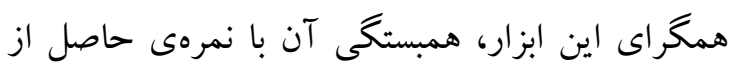

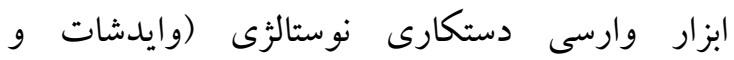

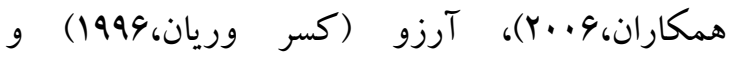

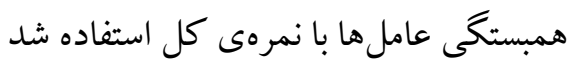

يافته ها ميانگين سن مشاركت كنند كان

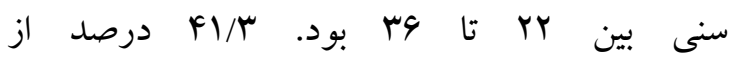

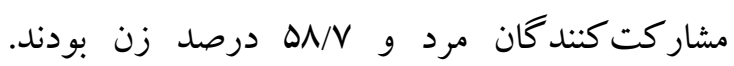
همجنين GF/V درصد دانشجوى كارشناسى ارشد و r/T درصد دانشجوى دكترى و F درصد دانشجوى سال آخر ليسانس بودند. به لحاظ وضعيت تاهل نيز V درصد مجرد و VQ/A وضعيت شغلى 19/1 درصد از مشار كت كنند كان بيكار و 1\%/9 ا درصد شاغل بود.

براى تعيين ساختار عاملى مقياس و وِاسخگگ ويى به سؤال

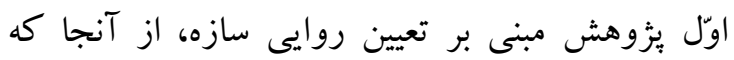

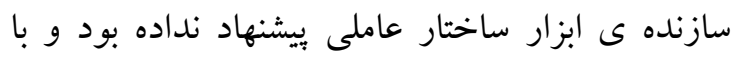

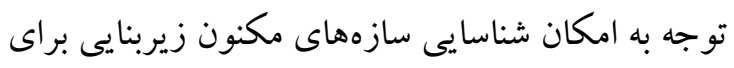
متغيرهاى مشاهدهدهى مقياس و نيز سنجش امكان تعميم دهى يكك ساختار مشخص به ديخر فرهنگها از تحليل عامل اكتشافى به روش تحليل عامل هاى محورى

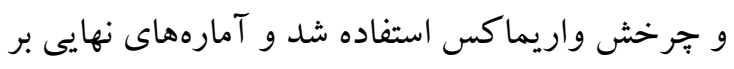
مبناى ماتريس جرخش يافتهى عاملها استخراج شد. ضريب KMO به دست آمده •9/، بود كه بيانگر
صورت ا= كاملاً مخالف و V= كاملاً موافق بود. روش القاى نوستالثى و آيتمهاى وارسى دستكارى توسط تحقيقاتى در آمريكا (جوهل و و همكاران، •1+r؟

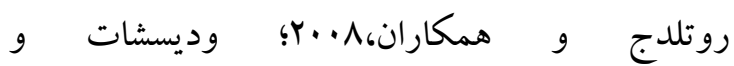

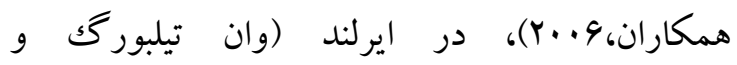
همكاران،r|r)

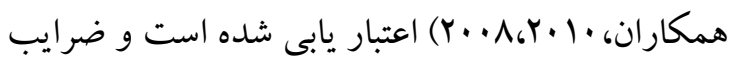
بهدست آمده نشان از مطلوب بودن بايايى( ضريب

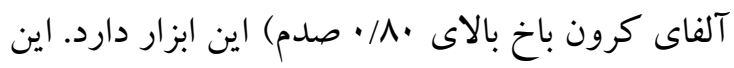

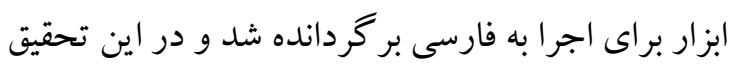
نيز نتايج گفته شده در مورد يايايى و روايى مورد تائيد قرار كرفت. مقياس آرزو (AI): مقياس هـ •ا سؤالى آرزو را كسر و رايان (1999) ساختهاند. اين مقياس شامل سه زيرمقياس جداكانه، اهميت، احتمال دست يابى و ميزان دستيابى رليى به آرزوهاى ذاتى و بيرونى است كه ساختار عاملى،

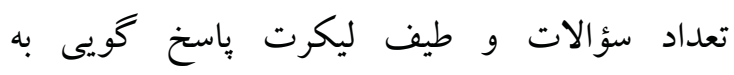
سؤالات، در هر سه زيرمقياس مشابه است .اين مقياس شامل دو عامل سطح دوم آرزوهاى ذاتى و بيرونى

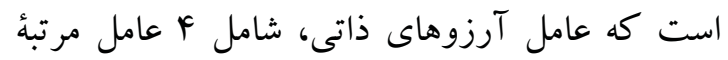
اول (رشد شخصى، ارتباط صميمانه و متعهدانه بادى

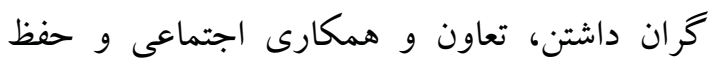

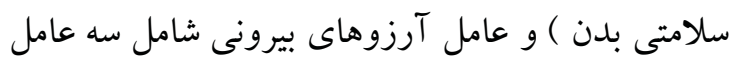

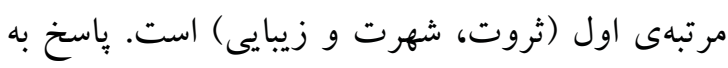
كويه هاى آن در طيف ليكرت V درجهاى ( آ اصلاً و

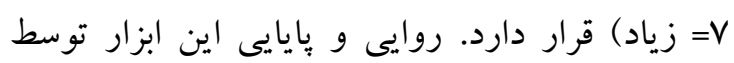

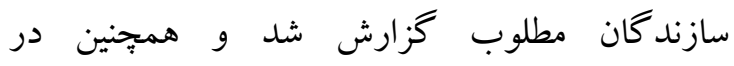

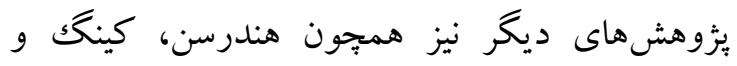

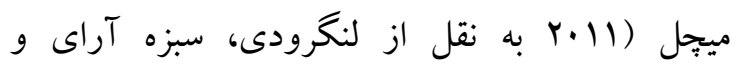

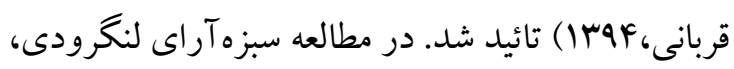
سرافراز و قربانى (AF (IF) همسانى درونى زيرمقياس هاى اهميت، احتمال دستيابى و ميزان دستيابى به 
بالاتر از يكك و شيب منحنى اسكرى بود. بر اين اساس

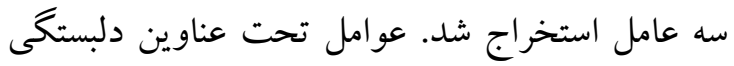
هاى گذشته و ميل به خانه و صفاى كذشته نامخذارى

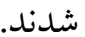

بسندگى متيرها در ماتريس همبستكى و مقدار آماره ى خى دو بارتلت 1994 (P>0.001، P>171) بود كه بيانگر كرويت ساختار ماتريس همبستخى براى انجام تحليل عاملى است. ملاكك تعيين عوامل ارزش ويزه

جدول (1). نتايج تحليل عامل اكتشافى يرسشنامهى نوستالزى

\begin{tabular}{|c|c|c|c|c|}
\hline صفاى كذشته & 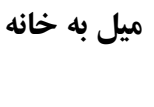 & دلبستكى كذشته & كويه هاى يرسشنامهى نوستالزى باجو & كويه ها \\
\hline & & $\cdot / N$ & شخصى كه دوست داشتيد & -9 \\
\hline & & .190 & موسيقى كه دوست داشتيد & $-\phi$ \\
\hline & & $\cdot 19$ & دوستانى كه داشتيد & $-Y$ \\
\hline & & $\cdot / \Delta \Delta$ & كارهايى كه انجام داديد & $-\Lambda$ \\
\hline & & $\cdot / \Delta F$ & مكانهايى كه دوست داشتيد & $-\varphi$ \\
\hline & & $\cdot / D F$ & داشتن كسى كه به او وابسته بوديد & -11 \\
\hline & & $\cdot / 4 q$ & احساساتى كه داشتيد & -1 \\
\hline & & $\cdot / \pi 4$ & حيوان يا حيوانات دست آموزى كه داشتيد & -19 \\
\hline & & $\cdot / A Y$ & قهرمانانى كه دوست داشتيد & $-r$ \\
\hline & $\cdot / \mu \Lambda$ & & خانهاى كه شما در آن زندگى مى كرديد & -19 \\
\hline & $\cdot / \mathrm{NI}$ & & مدرسهاى كه در آن درس مى خوانديد & -14 \\
\hline & $\cdot 194$ & & جامعهى آن زمان (وضع جامعه) & -10 \\
\hline & .191 & & مردم آن زمان (نحوهى بودن مردم) & -9 \\
\hline & $\cdot / 4 \Lambda$ & & مسجد يا يرستشگاهى كه در آن عبادت مى كرديد & -11 \\
\hline & $\cdot / 44$ & & برنامههاى تلويزيونى كه تماشا مى كرديد & -11 \\
\hline$\cdot / \Delta \mathrm{V}$ & & & نبودن اثرى از غم و شر در آن زمان & $-1 \mathrm{r}$ \\
\hline$\cdot / \Delta F$ & & & خانو اده بزرگى كه در آن زندگى مى كرديد & -1 \\
\hline$\cdot / \Delta r$ & & & 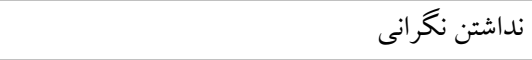 & $-r$ \\
\hline$\cdot / A V$ & & & اعياد يا تعطيلى هايى كه تجربه كرديد & -14 \\
\hline$r / Y 4$ & $r / l r$ & $r / F$. & ارزش ويزه & \\
\hline \multirow[t]{2}{*}{$11 / 19$} & $19 / 4 Y$ & $I V / 9 F$ & واريانس تبين شده (يس از جرخش) & \\
\hline & $F 9 / Y q$ & & واريانس كل تبيين شده & \\
\hline
\end{tabular}

دستكارى) و عاملهاى پرسشنامهى نوستالزى آورده شده است. جنان كه مشاهده مىشود هر سه عامل يرسشنامهى نوستالثى با آزمون وارسى دستكارى نوستالزى و مؤلفههاى آرزو رابطهى معنادار مطلوبى

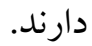

براى بِاسخكويى به سؤال دوم يزووهش مبنى بر روايى

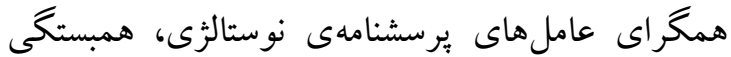
اين مقياس با مقياسهاى ديخر ملاكك قرار گرفت. در جدول (Y) نتايج ماتريس همبستكى بيرسون ميان متغيرهاى يثزوهش (مؤلفه ياى آرزو، آزمون وارسى 
جدول (r): ماتريس همبستكى متغيرهاى يزوهش (روايى همكر او همبستكى بين مؤلفهها)

\begin{tabular}{|c|c|c|c|c|c|c|c|c|c|c|c|}
\hline 11 & 1. & 9 & $\wedge$ & $\checkmark$ & 9 & $\Delta$ & $p$ & $r$ & $r$ & 1 & متغيرها \\
\hline & & & & & & & & & & 1 & ا - وارسى نوستالزى \\
\hline & & & & & & & & & 1 & $\cdot / Y^{\mu^{* * * * *}}$ & r- ميل به خانه \\
\hline & & & & & & & & 1 & $\cdot 19 r^{* * * *}$ & $\cdot / r Y^{* * *}$ & r- صفاى كذشته \\
\hline & & & & & & & 1 & $\cdot 19 .^{. * * * *}$ & 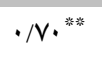 & $\cdot / r V^{* * * * *}$ & ץ- دلبستگى هاى حذشته \\
\hline & & & & & & 1 & $\cdot / r 9^{* * * *}$ & $\cdot / \Gamma^{* * * *}$ & $\cdot / Y F^{* * * *}$ & $\cdot / Y 9^{* * * *}$ & ه- آرزوى ثروت \\
\hline & & & & & 1 & $\cdot 190^{* * * *}$ & $\cdot / \mu F^{* * * * 2}$ & $\cdot / Y)^{* * * * * *}$ & 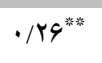 & 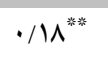 & 9- آرزوى شهرت \\
\hline & & & & 1 & $\cdot / V \cdot * * *$ & $\cdot 19 V^{* * * *}$ & $\cdot / r Q^{* * * * *}$ & $\cdot / r 9^{* * * *}$ & $\cdot / I V^{*}$ & $\cdot / 19^{* * * * *}$ & Y- آرزوى زيبايى ظاهر \\
\hline & & & 1 & $\cdot|f|^{* * * * * 2}$ & $\cdot / q^{* * *}$ & $\cdot / \Delta 9^{* * * * * x^{*}}$ & $\cdot / Y 9^{* * * * *}$ & $\cdot / 19^{*}$ & $\cdot / I V^{*}$ & $\cdot / 11$ & ג-آرزوى سلامتى \\
\hline & & 1 & $\cdot / V Q^{* * *}$ & $\cdot / \mu \cdot{ }^{* * *}$ & $\cdot / f^{* * * *}$ & $\cdot / \Delta r^{* * * * *}$ & $\cdot / Y 4^{* * * *}$ & $\cdot / Y F^{* * * *}$ & $\cdot / Y^{* * * * *}$ & $\cdot / l f^{*}$ & 9-آرزوى رشد شخصى \\
\hline & 1 & $\cdot / \mathrm{V} \Lambda^{* * *}$ & $\cdot / V Q^{* * * *}$ & $\cdot / \Lambda^{* * * *}$ & $\cdot /\left.4\right|^{* * *}$ & $\cdot / \Delta \Lambda^{* * * *}$ & $\cdot / r \cdot * * * *$ & $\cdot / r \cdot{ }^{* * * * *}$ &.$/ / f^{*}$ & $\cdot / \Lambda^{* * * *}$ & • ا-آرزوى ارتباط صميمانه \\
\hline 1 & $\cdot 191^{* * *}$ & $\cdot / V r^{* * *}$ & $\cdot 199^{* * *}$ & $\cdot / 4 \cdot * *$ & $\cdot / 4 \Delta^{* * *}$ & $\cdot / \Delta \cdot{ }^{* * *}$ & $\cdot / \mu F^{* * * *}$ & $\cdot / r^{* * * *}$ & $\cdot / \mu \cdot * *$ & $\cdot / Y Y^{* * * * *}$ & |اجتماعى آرزوى همبستكى \\
\hline
\end{tabular}

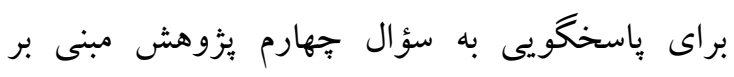

تفاوت هاى جنسيتى متغيرها از آمار توصيفى و آزمون تى مستقل استفاده شد. در جدول (r) شاخص هاى آمار توصيفى به همراه آزمون تى مستقل جهت بررسى تفاوت جنسيتى در متغيرهاى مورد بررسى در بيزوهش ارائه شده است. جنان كه مشاهده مىشود ميانخين نمرهى دختر ان در بعضى از عامل هاى نوستالثىى (ميل به خانه و صفاى كذشته) به طور معنادارى بيشتر از يسران
براى سنجش يايايى يرسشنامهى نوستالثى از ضريب بهدست آمده از روش آلفاى كرونباخ استفاده شد كه

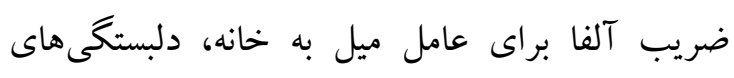
كذشته، صفاى كذشته و نمرهى كل نوستالزى به به ترتيب، همبستكى ميان عاملهاى ويرسشنامهى نوستالثى بين

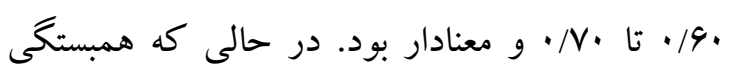
عاملها با نمرهى كل مقياس در محدودهى V9/· تا

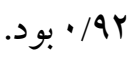

جدول (r). شاخصهاى توصيفى به تفكيكى جنسيت و نتايج آزمون تى مستقل

\begin{tabular}{|c|c|c|c|c|c|c|c|}
\hline \multirow{2}{*}{$\mathbf{T}$} & \multicolumn{2}{|c|}{ 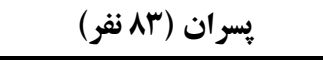 } & \multicolumn{2}{|c|}{ دختر ان (111 ا نفر) } & \multicolumn{2}{|c|}{ كل نمونه ( ا ب نفر) } & \\
\hline & انحر اف معيار & ميانكين & انحراف & ميانكين & انحراف & ميانكين & \\
\hline - /A9 & $\varphi / \cdot v$ & $11 / r p$ & $r / \Delta 1$ & $11 / \lambda 1$ & $r / v \Delta$ & $11 / 94$ & وارسى تلقيح نوستالثى \\
\hline$r / r \mid *$ & 1.119 & $r \cdot 1 \cdot r$ & $11 / 4 d$ & $r r / \Delta l$ & $11 / \cdot 9$ & $r r / \cdot r$ & ميل به خانه \\
\hline r/৭९ *** & $V / 1$. & $r \mid / 91$ & $Y / Y$ & $r F / Y \Lambda$ & $V / 91$ & $r r / P r$ & صفاى حذشته \\
\hline $1 / 49$ & $|\Delta| \cdot \Delta$ & $P \Delta / r \Lambda$ & $19 / 9 V$ & $P \wedge / Y \Delta$ & $\mid 91 \cdot Y$ & PV/TG & دلبستكى هاى حذشته \\
\hline
\end{tabular}


سه گانهى نوستالزى و تائيد جايگاه اين عوامل در تجربهى نوستالزى نشان مىدهد كه نوستالزى در جامعهى ما به تناسب فراخوانهاى آن، تجربهاى داراى ابزههاى متعدد است. عامل "دلبستخىهاى كذشته" جنان كه از محتواى سنجههاى آن بيداست، نشان از حسرت و ميل به روابط دوستانه، عاشقانه و بهطور كلّى آلى تعلقخاطرهايى است كه جوانان دانشجو در گذشتهى دور و نزديكك خود تجربه كردهاند. عامل " ميل به

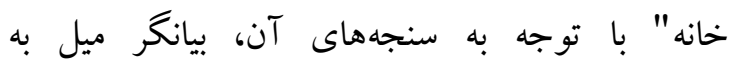
سكونت كاه و به طور كلّى ميل به "خانه" ایى است كه له تجربههاى ارتباطى و امنيت و جمعيت خاطر در آن رقم خورده است و همجينين جنبه هايى از زمان و مكان كه با نهان اين جمعيت خاطر تداعى مىشوند. و در نهايت عامل "صفاى گذشته" بيانگر نوعى احساس صلح و فقدان

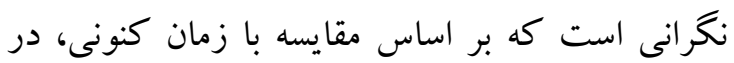
تجربهى فرد بروز و ظهور مى يابد. به عبارت ديخر وضعيت "اكنون" ناگوار است و يا جندان گوارا نمىنمايد و گوارايى و خواستنى بودن زمانهايى در

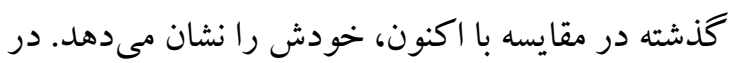
تبيين اين يافته، توجه به تمايل عمومى جامعهى ما به بازنشر خاطرات كذشته و ارزش و اهميت نوستالزى در ادبيات و شعر شاعران و نويسند گان ما (براى مثال نغاه كنيد به شريفيان، صيادىنزاد، قربانيور و حسن يور، بهوبا ) نشان مىدهد كه هيجان نوستالزى در تجربهى جامعهى ما (و به تناسب در ميان دانشجويان) داراى بروز و ظهور و ابعاد

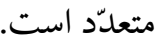
روايى همخراى اين ابزار نيز در رابطه با آزمون وارسى معى إسى

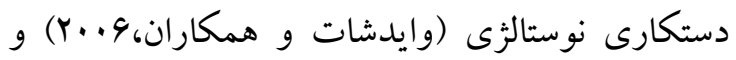
مؤلفه هاى هفت گانهى مقياس آرزو (كسر ورايان،1999) تأييد شد. به عبارت ديخر، همبستخى

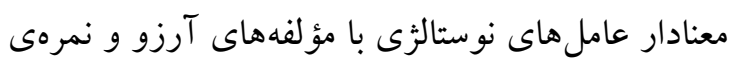

\section{بحث و نتيجه كيرى}

نتايج به دست آمده بر نمونهى دانشجويى اين بئوهش

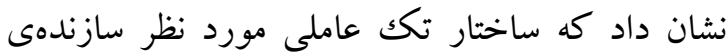
ابزار، قابل تجديد نظر بوده و بر اساس نتايج تحليل عامل اكتشافى نشان داده شد كه مىتوان يكك ساختار سه عاملى را براى اين سازه بيشنهاد كرد كه اين سه عامل ارزش ويزٔى قابلتوجهى داشتند و واريانس قابل توجهى از مقياس را قابل تبيين كردند. نتايج تحليل

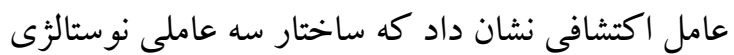
علاوه بر بيشينه كردن واريانس قابل تبيين و همجنين تفسير يذيرى ماتريس همبستخى عامل ها، فهم بهترى از يبيجيد گیى تجربهى نوستالزى به دست مى دهد. در اين راستا با نظر به سنجههاى بار شده زير هر عامل، عناوين

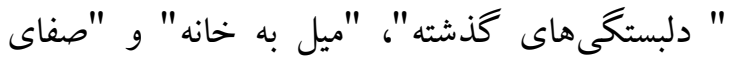

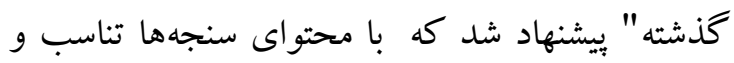

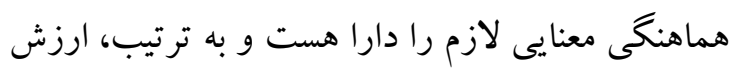
ويزّى هر عامل در ساختار سازمى نوستالزى را نشان مىدهد. به اين ترتيب، مدل سه عاملى نوستالزى از

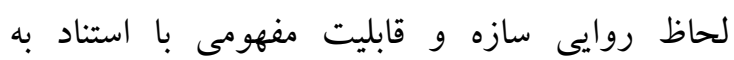
دادههاى اين بزوهش بيشنهاد مى شود. نتيجه گيرى فوق،

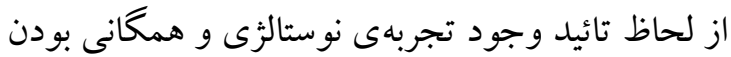
آن و همجنين داشتن فراخوانهاى متعدد با يافته هاى

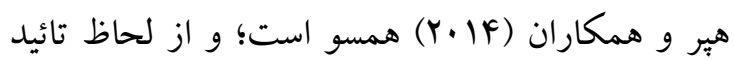
كلّى روايى سازمى ابزار (فارغ از تعداد عاملها) با همان تحقيق سازندهى ابزار (بانو، (1990) و و تحقيقات انجام گرفته بر مبناى آن (براى مثال نكاه كنيد به ) همسو است. افزون بر اين، تحقيقات متعدد نشان دادهاند

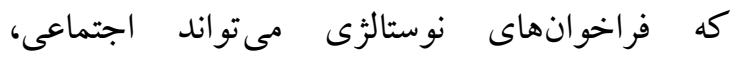

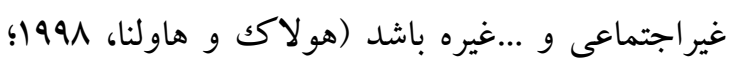

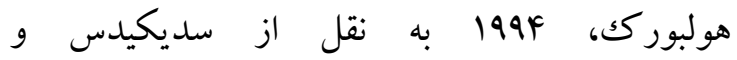
همكاران، (Y) و بنابر اين تجربهى نوستالزى مىتواند

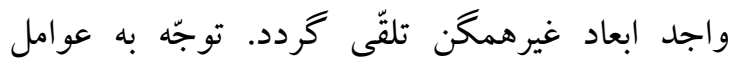


نوستالزى گرايى قابليت تفكيك از يكديگر را دارا هستند و از اين قاعده كه مؤلفهها بايستى با نمرهى كل

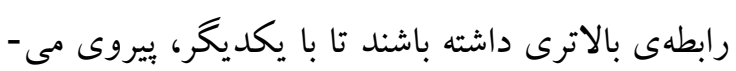

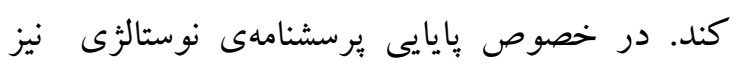

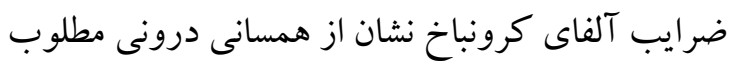
اين ابزار دارد كه با يافتهى باجو (1991)، 1990) در اين

زمينه همسو است.

در مورد نقش جنسيت، شاخصهاى توصيفى و نتايج آزمون تى مستقل مربوط به عاملهاى يرسشنامهى

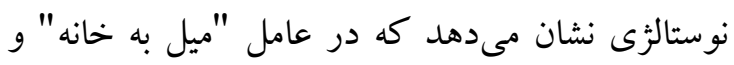
"صفاى كذشته" تفاوت معنادارى در ميانخين دختران و ״سران وجود دارد. در مورد اين يافته بعضى از

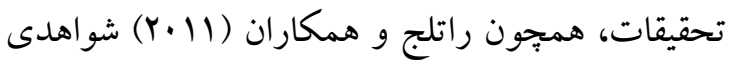
مبنى بر نقش جنسيت در اين زمينه گزارش نكردهاند ولى نقش آن را با توجه به نقش فرهنگ بن قابل بحث

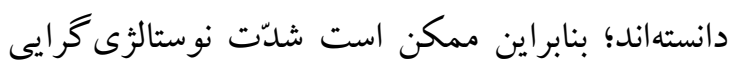
دختران در اين عاملها به نحوى بازنماى نارضايتى بيشتر دختران در وضعيت اكنون جامعهى ما باشد. اين

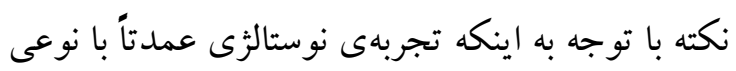

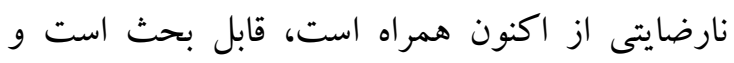
علاوه بر آن ممكن است نتيجه كيرى دربارهى نقش جنسيت به سن مشار كت كنند كان نيز وابسته باشد و اين مسئله نياز به تحقيقات جدا كانهاى دارد. اين يُزوهش بر آن بوده است كه خصوصيات

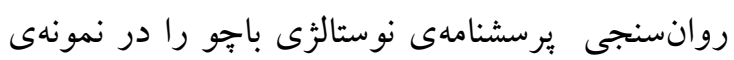
بركرفته از فرهنگك ايرانى آزمون كند و ميزان تعميم جذيرى مدل سنجشى آن را در ميان دانشجويان ايرانى تعيين نمايد. جنانجه در مقدمه آورده شد اهميت كاربرد ابزارى براى سنجش نوستالزى گرايى در تحقيقات

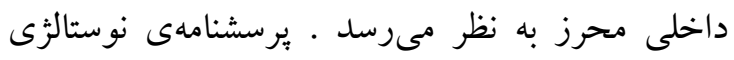
باجو (1990) يكى از مقياسهاى ير كاربرد و بـىبديل براى سنجش متعلق تجربههاى نوستالزيك است. بناتر
آزمون وارسى دستكارى نوستالثى نشاندهنده و مؤيّد

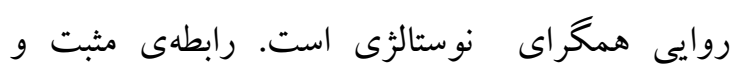
معنادار عوامل نوستالزّى با نمرهى اين ابزارها، به عنوان

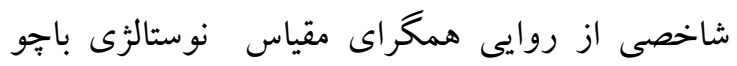

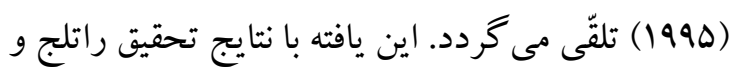

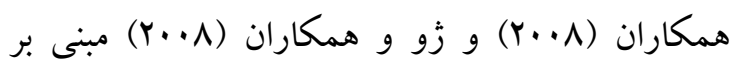
رابطهى همبستخى برسشنامهى نوستالثى با مقياس

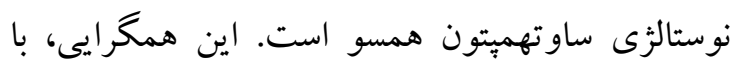

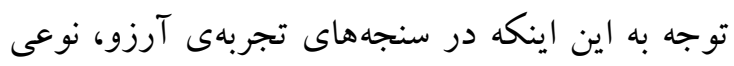

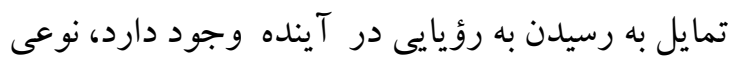
سنخيت با نوستالثى برقرار مى كند. مؤلفه هاى آرزو عبارت بود از " آرزوى ثروت"، "آرزوى شهرت بـ برديت

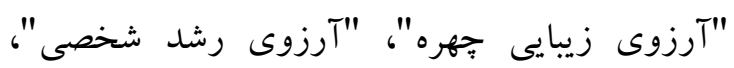

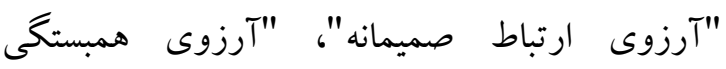

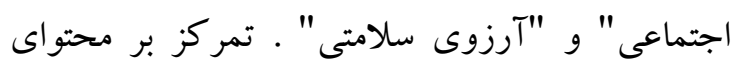

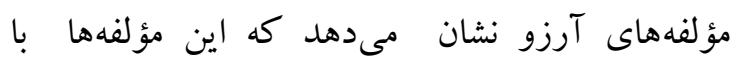
نوستالثى داراى نوعى تجانس هستند كه شايد بتوان كفت، حداقل بخشى از آرزوهاى فرد، شكل رو به به

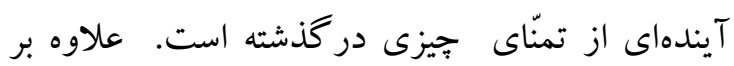
آنهم در نوستالزى و هم در آرزو، فرد از وضعيت

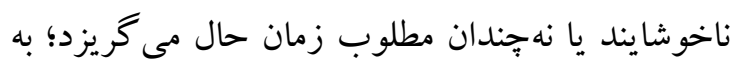

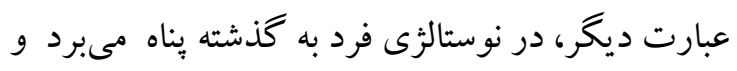

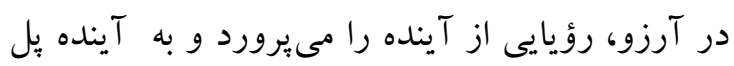

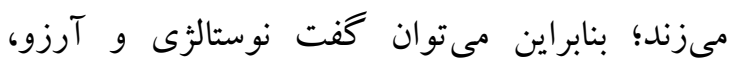
تجربههايى داراى نوعى اشتراكك محورى هستند. همجنين آزمون وارسى دستكارى نوستالثَى نيز پِ بس از يكك تكليف القاح نوستالزى، ميزان نوستالزيكى شدن افر اد در لحظه را مىسنجيد.

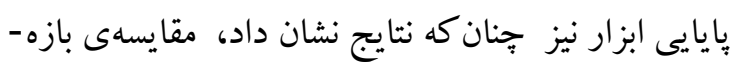

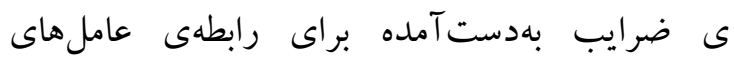

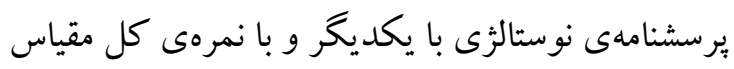

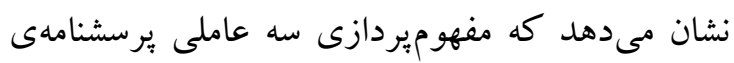


survey research (quantitative data analysis). Tehran: Lavieh Publication[Persian].

Sarmad Z, Bazargan A, Hejazi E (2011). Research methodologies in behavioral sciences. Tehran: Agah publications[Persian].

Sayyadi nejad, R; Ghorbanpoor,H and Hasanpoor, M (2015). Barresie zaminehaye nostalgi dar soroodehaye Nazokolmalaeke and Foroogh Farokhzad. Journal of Lyrical Literature Researches, 22, 209226[Persian].

Sedikides, C., \& Hepper, E. G. (2009). Selfimprovement. Social and Personality Psychology. 3(6), 899-917

Sedikides, C., Wildschut, T., Amdt, J., \& Routledge, C. D. (2006). Affect and the self. In J. P. Forgas (Ed.), Affect in social thinking and behavior: Frontiers in social psychology (New York, NY: Psychology Press.

Sedikides, C., Wildschut, T., Routledge, C., Amdt, J $(\tau \cdot 1 \xi)$. Nostalgia counteracts selfdiscontinuity and restores self-continuity. European Joumal of Social Psychology, Eur. J. Soc. Psychol. Published online in Wiley Online Library.

Sedikides, C., Wildschut, T., Routledge, C., Amdt, J., Hepper, E \& Zhou, X. (2015). To Nostalgize: Mixing Memory with Affect and Desire. Advances in Experimental Social Psychology, Volume 51.

Sharifian. M (2007). Barresie farayande nostalgi dar ashaare sohrab sepehri. Journal of Lyrical Literature Researches, 5, 51-73[Persian].

Tabachnick, B and Fidell, L (2017). Using Multivariate Statistics( Translate by Pasha Sharifi, H and colleague's). Tehran: Roshd publication

Taherinia, A; Abbasi, N (2012). Barresie padideye nostalgi dar ashaare Ibne Khafaje. Joumal of Lyrical Literature Researches, 17, 149172[Persian].

Van Tilburg, W. A. P., Igou, E. R., \& Sedikides, C. (2013). In search of meaningfulness: nostalgia as an antidote to boredom.Emotion, 13(3) : 450-61

Wildschut, T., Sedikides, C., Amdt, J., Routledge, C. (2006). Nostalgia: Content, triggers, functions. Journal of Personality and Social Psychology, 91, 975-993.

$$
\begin{aligned}
& \text { نتايج به دست آمده در اين تحقيق، يرسشنامهى } \\
& \text { نوستالزى گرايى باجو (1990) با ساختار سهعاملى مورد إنه } \\
& \text { بحث، داراى روايى سازه، همخرا، پايايى و قدرت } \\
& \text { افتراق قابلقبول است و محققان داخلى مىتوانند از اين } \\
& \text { ابزار براى بيشبرد مسائل تحقيقاتى مرتبط با اين هيجان } \\
& \text { استفاده كنند. }
\end{aligned}
$$

$$
\begin{aligned}
& \text { تشكر و سياسگذارى } \\
& \text { در بايان از دانشجويان دانشگاه شيراز كه با مشاركت }
\end{aligned}
$$

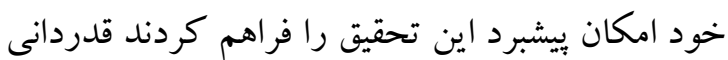

$$
\begin{aligned}
& \text { مى گردد. }
\end{aligned}
$$

\section{References}

Batcho, K. I. (1995). Nostalgia: A psychological perspective. Perceptual and Motor Skills, 80,131-143

Batcho, K. I. (2013a). Nostalgia: The bittersweet history of a psychological concept. History of Compass, 3, 899-917.

Hepper, E. G., Wildschut, T., Sedikides, C., Ritchie, T. D., Yung, Y.-F., Hansen, N., et al. (2014). Pancultural nostalgia: Prototypical conceptions across cultures. Emotion, 14(4):733-47

Juhl, J., Routledge, C., Amdt, J., Sedikides, C., \& Wildschut, T. (2010). Fighting the future with the past Psychology, 16, 165-176.

Kasser, T., \& Ryan, R. M. (1996). Further examining the American dream: Differential correlates of intrinsic and extrinsic goals. Personality and Social Psychology Bulletin, 22, 280-287. Nostalgia as an antidote to boredom. Emotion, 13,450-461.

Routledge, C., Sedikides, C., Wildschut, T., \& Juhl, J. (2013). Finding meaning in the past: Nostalgia as an existential resource. In $\mathrm{K}$. Markman, T. Proulx, \& M. Lindberg (Eds.), The psychology of meaning (pp. 297-316). Washington, DC: American Psychological Association.

Safari Shali R, Habbibpour Gatabi K (2012). A comprehensive guide to use SPSS in 
Wildschut, T., Sedikides, C., Amdt, J., Routledge, C. (2006). Nostalgia: Content, triggers, functions. Journal of Personality and Social Psychology, 91, 975-993.
Zhou, X., Wildschut, T., Sedikides, C., Chen, X., \& Vingerhoets, M.J. (2012). Heartwarming Memories: Nostalgia Maintains Physiological Comfort. Emotion. 12 (4): 678-84. 